Historic, Archive Document

Do not assume content reflects current scientific knowledge, policies, or practices. 

DORR D. BUELL Maplewood Farm

The Seed

Potato Man of the North

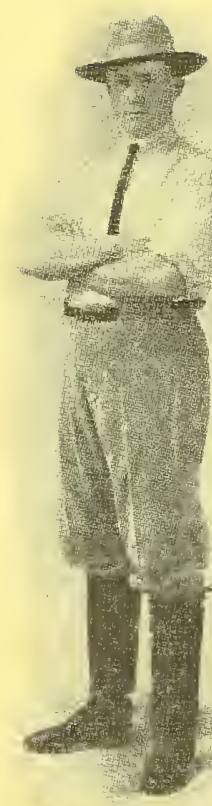

D. Torm Stuart. Clashuigtor

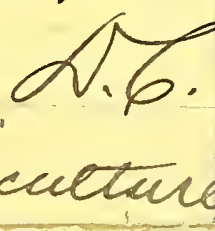





\section{BUELL'S RUSSET RURAL}

( IMPROVED LATE PETOSKIEY)

\section{Note Smoothness and Shallow Eyes}

\section{They Do Not Peel to Waste}

BUELL'S RUSSET RURAL, as shown above is a round white variety, with shallow eyes. The skin is beautifully netted, "russety," and slightly tough which makes them practically scab proof. On account of the firm smooth skin they can be safely dug when not quite ripe without marring. They nestle closely together in the hill, extra large "yielders," excellent "cookers," especially good baked, and the best "keepers" known. The vines are vigorous and a healthy dark green color; blossoms purple. I have grown them for several years and by judicious seed selection and correct cultural methods have greatly improved on the original stock, The Late Petoskey, which is conceded to be the best all around potato known.

In the Heart of Northern Michigan the soil and climate are ideal for the growing of good seed potatoes. Our gravelly loam soil is new and not full of potato disease as in many of the older potato growing sections. We are about 1000 feet altitude. The nights are cool and the days but moderately warm and the growing season is comparatively short, which gives my seed potatoes the "Hustle Habit." This hustling seed taken further south will grow right away from the lazy southern grown seed, mature earlier and produce a better crop. No crop is so greatly improved by the judicious change of stock as potatoes. The best is none too good. Poor seed is expensive at any price.

The price is $\$ 1.50$ per bushel for choice, and $\$ 1.25$ per bushel for second size, F. O. B. Elmira. While we do not recommend planting small seed, some of our best growers prefer the "egg size," planted whole.

Order early. I will ship when the weather permits. These potatoes I have are grown by me right here on Maplewood Farm, in the heart of Northern Michigan and I guarantee perfect satisfaction.

REMEMBER, poor seed is largely (responsiblef for the low yield per acre in the United States. It will pay song tog gethe best from

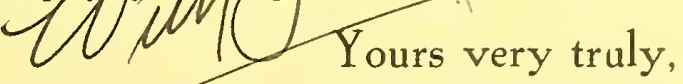

DORR D. BUELL, The Seed Potato Man of the North, Elmira, Michigan. 


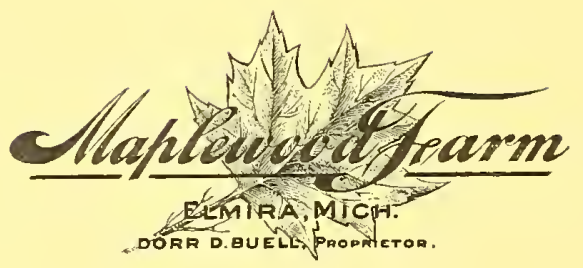

WE Also RAISE REgISTERED PERCHERONS, HOLG'TEINS, ANGUS, SHROPSHIRES AND DUROCS. 



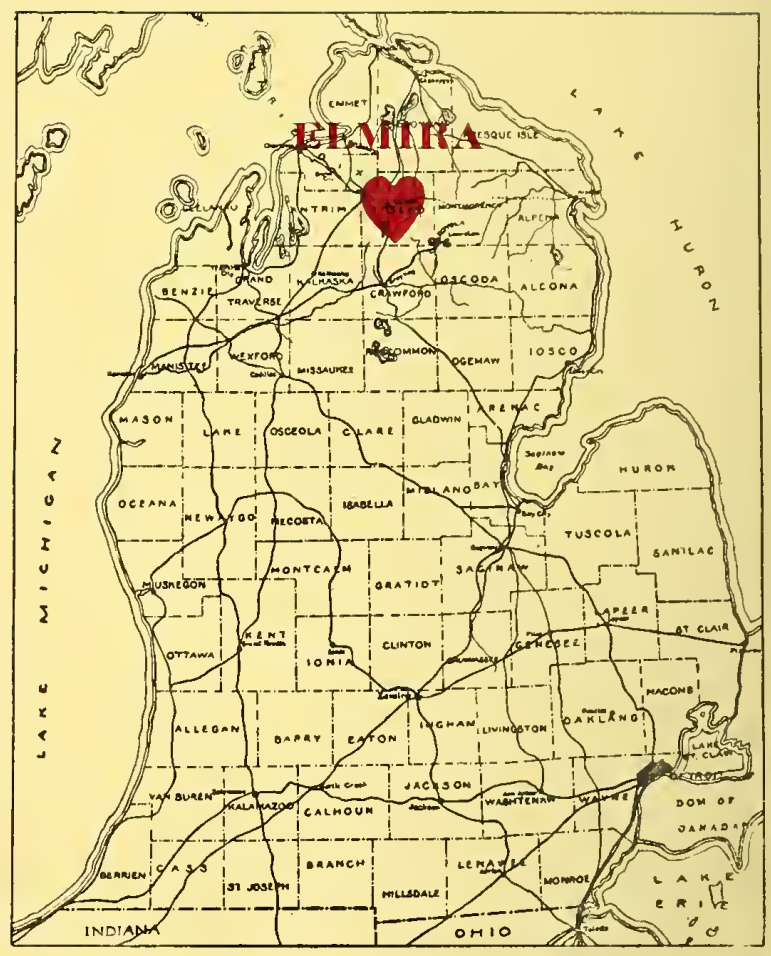

In the Heart of North Michigan 